\title{
Social Contract and the Governments Legitimacy
}

\author{
Nertil Bërdufi
}

PhD Candidate, University of Tirana, and Lecturer at "Hëna e Plotë" Beder University, nertilberdufi@yahoo.co.uk

\section{Desara Dushi}

PhD Candidate, University of Bologna, desaradushi@gmail.com

\author{
Doi:10.5901/mjss.2015.v6n6s1p392
}

\begin{abstract}
The social contract doctrine has been one of the most influential theories within Western moral and political theory. The reasons for it being enormously influential are because it addresses the source of sovereign's legitimacy, conception of freedom of individuals and equality, and the issue of consent. But in a current situation of crisis of democracy, reflected also in the crisis of legitimacy of governments, is the social contract theory still relevant? In the first chapter will be presented the common features but also the differences of the ideas of classical contractarians, Hobbes, Locke and Rousseau. Even though they have the same general idea, they differ in a main point that is the power that each of them gives to the government, which will be explained in this chapter. Through this comparison, we will be able to distinguish between them and understand which idea is more suitable for the society, obviously, if it is suitable at all. Finally, in the last chapter, the relevance of the social contract today is put into question. Is the theory of the social contract still applicable, or it has lost its relevance. What justifies its relevance and application after so many years? And what happens if the government does not comply with its obligations? Can people challenge it, or they must just wait and hope for things to get better?
\end{abstract}

Keywords: social contract, government, legitimacy, sovereign.

\section{Introduction}

The traditional social contract theory is a way by which people, in order to escape the state of nature, an insecure state of unavoidable war, implicitly agreed to give away some of their individual freedoms to a political ruler, a State, in order for the State to better protect some more important needs and rights to them. This is how Thomas Hobbes, John Locke and Jean Jacques Rousseau, and later other philosophers, justified the establishment of a State, and developed a theory called the social contract. The social contract doctrine has been one of the most influential theories within Western moral and political theory. The reasons for it being enormously influential are because it addresses the source of sovereign's legitimacy, conception of freedom of individuals and equality, and the issue of consent. But in a current situation of crisis of democracy, reflected also in the crisis of legitimacy of governments, is the social contract theory still relevant?

In this paper will be described the theory of social contract by focusing on the three classical proponents, Thomas Hobbes, John Lock and Jean Jacques Rousseau, and comparing them. We intent to assess whether it is still relevant in the contemporary world with regards to the issue of government legitimacy. Lastly we will explain the cases in which people can challenge their government, by including relevant examples.

We think social theory is the basis of the current functioning of governments. So it is necessary to study about it in order to understand in a clearer way the essence of the government and its legitimacy. It also helps in understanding why we should obey to the law, and if people can punish the government if it doesn't fulfill its functions. In today's world, in which democracy and legitimacy of power are in crisis, it is essential to know the meaning on the concept of legitimacy, which is best explained in the social contract theory.

In order to best describe and analyze the theory of social contract and its relevance in the world we are living, we will try to answer this question: In a current situation of crisis of democracy, reflected also in the crisis of legitimacy of governments, is the social contract theory still relevant?

In the first chapter we will present the common features but also the differences of the ideas of classical contractarians, Hobbes, Locke and Rousseau, because even though they have the same general idea, they differ in a main point, that is the power that each of them gives to the government, which will be explained in this chapter. Through this comparison, we will be able to distinguish between them and understand which idea is more suitable for the society, 
obviously, if it is suitable at all. Finally, in the last chapter, the relevance of the social contract today is put into question. Is the theory of the social contract still applicable, or it has lost its relevance. What justifies its relevance and application after so many years? And what happens if the government does not comply with its obligations? Can people challenge it, or they must just wait and hope for things to get better?

In conclusion, Hobbes, Locke and Rousseau are considered to be the forerunners of the concepts of individualism, liberalism and equality among people, and they have also made a huge contribution in developing the concept of political power and government authority and legitimacy. Their theory is still appreciated and relevant because it is essential in order to understand the source of government legitimacy and is considered to be a revolutionary work as their contribution to the development of civil society is indisputable.

The theory of social contract is a very famous concept, which importance in nowadays world is still relevant. This is why there are a lot of authors, sociologists, philosophers, academicians, scholars etc, who have written about it. So there are a lot of sources about this topics, and in many different views, which helped us build a better idea of the way of constructing this paper.

\section{Classical Social Contract Theory}

Even though the theory of social contract existed since in the ancient Athens, through Socrates, its importance is viewed later on, with Hobbes's theory of social contract, which was then followed also by the theories of Locke and Rousseau. These theories had a great impact in the society and helped to give a better shape and improve the government regime of not only the time when they were proclaimed but they also have a great influence in our times. In the following subchapters will be explained one by one the theories of Hobbs, Lock and Rousseau.

\subsection{Common features}

According to the classical social contract theories, at the begging people lived in a state of nature, where there were no laws to obey to and no government to control them. Because people did not cooperate with each-other and cared only of their individual interests, they were constantly fighting with each-other. To overcome this situation they agreed to form a different society, through a social contract which would make it possible to live in peace and harmony.

The three most influential philosophers which elaborated the classical social contract are Hobbes, Locke and Rousseau. The three of them stated that people should seek protection of their lives, rights and properties, a protection which could be reached only through a social contract. This was the best way to form a society where all respect each other.

They also claimed that, in order for this society to function, it is needed an authority to obey to and that people should give all or some of their rights to this authority. This authority will guarantee to everyone the protection of their lives and property. So people must agree to renounce to some or all of their rights which they had in the state of nature, and must obey to an individual or a group of individuals who will have the power to enforce the social contract. Thus, the three above mentioned philosophers were of the idea that free will of individuals, expressed or even tacit, is essential for the social contract, even though their definitions of the free will are different.

\subsection{The issue of legitimacy of government}

\subsubsection{Hobbes and the legitimacy of government}

Central to Hobbes's theory of creating the government through a social contract are the notions of liberty, will and representation and he gives great importance to the clarification of the definitions of these words. He defines liberty as the lack of external barriers to human movement and power. ${ }^{1}$ Hobbes claims that there is a relation between liberty and the will of individuals, because a free person can do whatever he/she has the will to do, without limitations, barriers or restrictions. ${ }^{2}$ This unlimited liberty is not the same as the freedom of individuals ruled by a government. In this case, humans are bound by "artificial chains" called civil laws, by which individuals have put themselves under the rules of the

${ }^{1}$ Hobbes, Thomas. Leviathan. Yale University Press, 2010, 1651., pg. 84.

2 Evers, Williamson M. "Social Contract: a Critique ." Journal of Libertarian Studies, Vol. 1, No. 3, 185-194. Pergamon Press, Great Britain, 1977.pg 187. 
sovereign. ${ }^{3}$

As we can understand, Hobbes's idea is that political legitimacy and moral obligations are approved by the free will of people. According to Hobbes, it is the duty of every person to use his own will when deciding to transfer the rights to others or to abandon their rights through a voluntary act. ${ }^{4}$ So, according to him, the will is a moral choice to voluntarily create obligations. This is why, for Hobbes, the will is the essence of contracts. ${ }^{5}$

Social contract according to Hobbes is an agreement by all individuals to abandon all their powers and to allow the new sovereign to fully use his power without any obstacle by his subjects. ${ }^{6}$ It is understandable that there is no equality between the parties in Hobbes's social contract, the sovereign is absolute. And Hobbes claims that it was the free will of the citizens to create such a regime, and to be ruled by a chosen representative, the sovereign.

But what about regimes created through conquest? Can we talk about free will in these cases? Hobbes explains that also in this case, people express their free will to be ruled by the conqueror because they fear of the death. When they are faced with the death from the conquerors, they immediately express their free will to be governed by them and give up their rights and powers to the new sovereign. Thus, also this kind of sovereign owns the will of his citizens to be their representative.

To other philosophers, who say that contracts created through force and fear cannot be valid, Hobbes responds that it is enough for a person to have the bodily liberty and to not be kept into chains. This raises for him the duty to obey to his sovereign in everything. ${ }^{7}$ Hobbes states that there is not much difference between governments created through the social contract and those created through conquest. Both types of governance are created by surrender or by giving up of the rights and both types of obligations can be set up without any expressed declaration of will, because according to Hobbes contracts can be created also with silence or tacit consent and resignation. ${ }^{8}$

Through his theory Hobbes explains some important terms such as representation, when one person can transfer the rights to another, the legitimacy of contracts made under force and violence, and the tacit consent as a way to create a valid contract, notions which are important for the further development of contract theories by the other philosophers.

\subsubsection{Locke and the legitimacy of government}

Lock claims that a person cannot enslave himself to someone else by free will, nor can he put himself under arbitrary power of another. ${ }^{9}$ So, Locke defines the concept of will as related to the person's judgment, and not as a decision induced by external pressure. ${ }^{10}$ However, Locke also states that when people leave the state of nature in order to join a social contract for forming a political society, they have to give up all their power, in order to achieve the scope for which they unite into the society, that is to give to a sovereign the authority to force men to cooperate because in the state of nature when there is no authority to control them, they are likely to start a war, which probably would never end. ${ }^{11}$ As we see, although Locke, like Hobbes, thinks that people should give up all their rights and power and pass them to the sovereign, the difference between the two is in the definition of the notion of will.

Locke, unlike Hobbes, does not approve the contract made upon fear and pressure. According to him, political obligations can derive only by a contract which is voluntarily accepted and approved by individuals, by which they submit themselves to someone else's will. ${ }^{12}$ This means that for Locke, the authority obtained through fear cannot be valid, and the obligations posed by this kind of authority are not binding and people should not obey. That is that the main thing that differentiates a conqueror from a legitimate governor is the consent of the citizens which are rules by him.

Like Hobbes, also Locke approves the tacit consent as a way of declaring the will for being part of the social contract. But the difference is that when talking about the right protected by the government through social contract, he mentions the notion of property. In fact, Locke goes further by stating that the social contract is inhered from the landlord

\footnotetext{
${ }^{3}$ Hobbes, Thomas. Leviathan. Yale University Press, 2010, 1651., pt. 1, chap. 21, p. 138-139.

4 Ibid., pt. 1, chap. 14, p. 86.

5 Ibid., pt. 3, chap. 40, p. 307.

${ }^{6}$ Ibid., pt. 1, chap. 14, p. 85.

${ }^{7}$ Evers, Williamson M. "Social Contract: a Critique ." Journal of Libertarian Studies, Vol. 1, No. 3, 185-194. Pergamon Press, Great Britain, 1977. pg 188.

${ }^{8}$ Hobbes, Thomas. Leviathan. Yale University Press, 2010, 1651., pg. 91.

${ }^{9}$ Locke, John. Two Treatises of Government. London, 1823. Pg., 402.

${ }^{10}$ Riley, Patrick. Patrick Riley, "Locke on 'Voluntary Agreement' and Political Power", Vol. 29, No. 1. United States: Western Political Quarterly, 1976., pg. 136-145

${ }^{11}$ Locke, John. Two Treatises of Government. London, 1823. pg. 377.

12 lbid.
} 
to his successor, which means that the inheritor of the land will be obligated to obey the rules of the contract which was approved by his ancestor, because together with the land he will inherit also the obligations to the government. ${ }^{13}$

Differently from Hobbes who was against natural law, by stating that people first look at their individual interests and not to the moral ties to one another, and claimed that the best government is that when the sovereign has absolute power over his citizens, Locke approved natural law. In his contract people consent to give their rights to someone they trust, in order to enforce natural law and to protect them because the moral obligations would be pointless if there were nobody that would execute them.

However, Locke does not bind future generations with the contract consented by their ancestors. ${ }^{14}$ This means that the legitimacy of the government depends not only to the consent of its founding people, but also to the consent of the future generations, which means that if they government does not function well, they can dismiss its legitimacy.

Locke gives an answer also to the question whether it is enough for the majority to give legitimacy to the government. Locke states that it is normal that the body moves in the direction in which there is a greater force applied..$^{15}$ He also claims that it is difficult to procure unanimous consent, at least for the reason that it may happen that not all the citizens can participate to the voting. ${ }^{16}$ We can conclude that Locke's theory of social contract is similar with Hobbes's theory, but it differs in the main point, that is the way how the power of the government is legitimated.

\subsubsection{Rousseau and the legitimacy of government}

According to Rousseau, a contract by which one gives all his rights to someone else is invalid as this contract turns that person into a slave. If such a contract is made, people cannot express their free will anymore, and cannot act freely. ${ }^{17}$ Rousseau's idea is to build a kind of relationship between citizens through which all citizens will be protected by the community and each of them will still have their free will and liberty. He states that by making the community the sovereign, people do not enslave themselves because slavery is when one person is personally dependent on another's will. 18

For Rousseau, giving yourself to the community, creating a popular representative government is the best way to guarantee your rights and freedom, as he defines freedom as "that condition which by giving each citizen to his country, guarantees him from all personal dependence". ${ }^{19}$ According to Rousseau, the popular sovereignty will create general and unbiased laws according to the common interests of the people..$^{20}$

Rousseau claims that in a contract of self-enslavement, the individual loses everything, all of his rights. So it cannot be a mutual contract as it is disadvantageous, and once the person has accepted it, he cannot take any action to dispute his sovereign. ${ }^{21}$

Rousseau's idea is the creation of a popular government which will make general rules. The members of this government should obey to the sovereign or be punished as violators of the social contract. ${ }^{22}$ In this type of organization, people will be governed not by one, but by a group of individuals. Rousseau approves the tacit consent of the people, and that contrary to Locke, no continual consent is needed as long as people stay silent and do not argue about the rules. ${ }^{23}$ As Rousseau says "to live in a country means to submit to its sovereignty."24

As a conclusion, it can be said in the end, also the social contract of Rousseau is a kind of self-enslavement contract, because the group or people who rule the society have the power to punish individuals even with a death penalty.

\footnotetext{
13 lbid., pg. 394.

${ }^{14}$ Riley, Patrick. Patrick Riley, "Locke on 'Voluntary Agreement' and Political Power", Vol. 29, No. 1. United States: Western Political Quarterly, 1976.

${ }^{15}$ Evers, Williamson M. "Social Contract: a Critique ." Journal of Libertarian Studies, Vol. 1, No. 3, 185-194. Pergamon Press, Great Britain, 1977.

${ }^{16}$ Locke, John. Two Treatises of Government. London, 1823. pg. 376.

${ }^{17}$ Rousseau, Jean Jacques. Social Contract. Simon and Schuster, 2010, 1762.

18 Ibid.

${ }^{19}$ Barker, ed. Social Contract. Oxford University Press, 1985.

${ }^{20}$ Rousseau, Jean Jacques. Social Contract. Simon and Schuster, 2010, 1762.

${ }^{21}$ Evers, Williamson M. "Social Contract: a Critique ." Journal of Libertarian Studies, Vol. 1, No. 3, 185-194. Pergamon Press, Great Britain, 1977.

22 Barker, ed. Social Contract. Oxford University Press, 1985.

${ }^{23}$ Ibid., pg. 191.

${ }^{24}$ Rousseau, Jean Jacques. Social Contract. Simon and Schuster, 2010, 1762.
} 


\section{The Social Contract Today, Government Legitimacy}

From the first time it was introduced to the world, social contract has constantly influenced the political shape of the states by framing the government legitimacy and describing the citizens' obligations. There is something very important about the social contract that makes it still relevant nowadays, which is the bases for the creation of a society, and it is the fact that it is the way to reach agreement among people. For example people can agree on how to maintain social justice and who should be in charge of doing this.

\subsection{What does legitimacy of governments mean}

According to Locke, government represents a social contract among people who have agreed to create a community where the majority rule, this because it is impossible to reach the consent of all. This means that a government is legitimate only if it has the consent of the majority of the governed, because the main source of sovereign power are the people, and a legitimate government must have their approval. ${ }^{25}$

Government legitimacy is a virtue of government institutions. ${ }^{26}$ Legitimacy includes political authority and political obligations. ${ }^{27}$ But where does a political regime take its legitimacy from? Social contract could still answer this question. As it was explained before, the government legitimacy arises from the will of its citizens, who pass all or some of their powers to one person or a group of persons which they chose to be their representatives, in order to better protect their rights.

By accepting to be a part of the social contract, the people agree to obey to the obligations set up for them by the sovereign chosen by them, in order to benefit from its protection. But the contract does not establish the final basis of the norms, it just sets up the method through which norms can be created in order to best fit to the social requirements. But this method is not unchangeable. However, the approval of this kind of social contract by the majority of the people is something very important as it is essential for the preservation of social justice.

As it was mentioned above, according to Hobbes government gains it legitimacy through the use of force, and accepts the tacit consent as a valuable form of signing the contract. Later, Locke and Rousseau develop the reasons of the tacit consent to enter a social contract, which are related to the benefits received of the residency. But again this cannot be enough reason for the legitimacy of a government. Government should protect people's lives, property, and other rights, and guarantee that no one will interfere in their rights. But however this is from where the government authority and legitimacy derived in the beginning and this system still continues to function nowadays.

\subsection{Classical contract theorists and government legitimacy today. When a government is no longer legitimate?}

All social contract theories require the individuals to fully or at least partially renounce to part of their rights to the governor which for Hobbes is the sovereign, for Locke the majority and for Rousseau the assembly of representatives. The reason for citizens accepting to restrict their freedom and obey to their rules is the will to have a better protection of their rights and freedoms by an external stronger power. The government has the duty to take care of its citizens and to fulfill their will. But what happens when the government does not fulfill its obligations and surpasses its legitimacy? Do citizens have the right to disobey to their government?

If we rely to Hobbes' social contract, human beings are deprived of free will and they should obey to their sovereign no matter what. But later with the theories of Lock and Rousseau this concept differed. According to these theories government legitimacy is based not only on the initial consent for its foundation but also on its well-functioning later on. This means that if the government does not fulfill its obligations, citizens can challenge it and chose another government. For instance, for Locke a political regime is legitimate if it complies with the natural law. In the moment when a government starts to act contrary to natural law, it is no longer legitimate and people are not obligated to obey it anymore, and they can even change it with another government which they think will better comply with the obligations and guarantee a better protection of their rights. This possibility of the citizens to challenge the authority of their government arises since with the classical social contracts but is still relevant in the currents relationships between

25 Encyclopaedia Britannica. http://www.britannica.com/EBchecked/topic/157129/democracy/233861/The-legitimacy-of-government (accessed November 2013).

26 Hoffmann, Bert. "The International Dimensions of Authoritarian Legitimation: The Impact of Regime Evolution." GIGA Research Programme: Legitimacy and Efficiency of Political Systems, December 2011.

${ }_{27}$ Paz-Fuch, Amir. The social contract revisited: The modern welfare state. Oxford: The Fundation for Law, Justice and Society. 2011. 
governments and citizens.

A fresh example of this could be the situation in Ukraine these days. Civil society has occupied the Independence Square protesting against their president's unexpected decision to not sign the trade agreement with the EU. ${ }^{28}$ This decision is not approved by the citizens, which have started an uprising and demand the resignation of the president Viktor F. Yanukovich and his government. ${ }^{29}$ Public fury is caused also because they do not want Russian influence in the decisions taken by their government about their country. As it can be understood, this is a perfect example of the civil society challenging their government because of not fulfilling its obligations derived from a 'social contract'. As a democratic government, chosen by the people, it is its duty to act in accordance with the society's will, and not against it. Once the government starts acting contrary to the civil society's will, people have the right to change it.

Another example of people challenging their government is the Albanian recent case regarding the demolition of Syrian chemical weapons in Albania. In October 2013, National Journal listed Albania among the main candidates where the Syrian chemical weapons would be destroyed. ${ }^{30}$ Some days later, the director of the program Green Cross International, Paul Walker, said that Albania had accepted to destroy the chemical weapons and that the decision would be made public after some days. ${ }^{31}$ But the government of Albania still wouldn't declare anything.

After hearing the news, Albanian environmental groups organized a manifestation in front of the Office of the Prime Minister. ${ }^{32}$ The protests continued for a week, increasing in number. On the $12^{\text {th }}$ November, the most massive protest ever was held and people gathered in front of the headquarters of the Prime Minister and in front of the American Embassy. It was one of the rare times when people protested against United States proposals. The protests spread throughout the country, and online petitions against the demolition of Syrian weapons were launched. ${ }^{33}$ Finally, the voice of the people was heard and Albanian government declared that they declined the American proposal and no weapons would be demolished in Albania. ${ }^{34}$ This was a great achievement of the Albanians, showing their power over the government chosen by them. It shows that people can challenge their government anytime their interests and welfare are not taken into account by the government.

\section{Conclusions}

The social contract is considered to be one of the most revolutionary theories which shifted the society. Its founding fathers, Hobbes, Lock and Rousseau, gave a great contribution to the later movements and changes that happened in the political thinking of the society.

Even though the three of them worked upon the same general idea of a contract through which people leave some of their rights in the hands of the sovereign in order for him to protect them and offer them a more secure life and property, their theories differ in some main points, which make a great difference in the status of the society. Their different methods to explain the state creation and development help to understand the relationship between people and their sovereign and how this idea has developed from Hobbes to Rousseau and up to today.

Social contract has constantly influenced the political shape of the states. It continues to be important in the political life because it is the basis for the creation of the society and it frames the government legitimacy. As Locke states government represents a social contract among people who have agreed to create a society where the majority rule.

${ }^{28}$ British Broadcasting Corporation http://www.bbc.co.uk/news/world-europe-25342698 (accessed December 2013).

${ }^{29}$ The New York Times http://topics.nytimes.com/top/news/international/countriesandterritories/ukraine/ (accessed December 2013).

30 The Nuclear Threat Initiative (NTI) http://www.nti.org/gsn/article/syrian-chemical-weapons-seen-likely-ship-albania-destruction/ (accessed December 2013).

31 Top Channel http://www.top-channel.tv/english/artikull.php?id=10279 (accessed December 2013); Gazeta online Panorama http://www.panorama.com.al/2013/11/13/pol-walker-interviste-ne-al-jazera-armet-kimike-siriane-do-asgjesohen-ne-shqiperi-vendimieshte-marre-publikohet-te-premten/ (accessed December 2013).

32 Portali albeu.com http://www.albeu.com/shqiperi/ambientalistet-proteste-para-kryeministrise-ndal-armeve-kimike-nga-s/130957/ (accessed December 2013); Gazeta online Panorama http://www.panorama.com.al/2013/11/07/ambientalistet-proteste-parakryeministrise-ndal-armeve-kimike-nga-siria/ (accessed December 2013); Portali albeu.com http://www.albeu.com/shqiperi/protestakunder-asgjesimit-te-armeve-te-sirise/131033/; (accessed December 2013).

${ }^{33}$ Gazeta online Panorama http://www.panorama.com.al/2013/11/12/prishtine-proteste-kunder-asgjesimit-te-armeve-kimike-ne-shqiperi/ (accessed December 2013); http://www.panorama.com.al/2013/11/13/revolte-e-fansave-ne-facebook-rama-pa-frike-nese-marrimvendimin-per-armet/ (accessed December 2013); Portali albeu.com http://www.albeu.com/shqiperi/protesta-ne-durres-e-elbasan-/131 760/; (accessed December 2013).

34 Gazeta online Panorama http://www.panorama.com.al/2013/11/16/rama-thote-jo-shqiperia-e-ka-te-pamundur-te-perfshihet-ne-njeoperacion-te-tille-feste-para-kryeministrise/ (accessed December 2013); http://www.panorama.com.al/2013/11/15/vendimi-i-rames-lajmine-mediat-boterore/(accessed December 2013). 
Thus, a government is legitimate only if it has the consent of the governed, because it is the people who give power and authority to the government. People accept to restrict their rights and to obey to a ruler in order to have a better protection of their rights and property by a stronger power, the power of the ruler. The government guarantees them protection of their rights and freedoms. This is why, when the government does not fulfill its obligations, derived from the contract, people have the right, and sometimes should challenge their government, and can even change their ruler or government with another one which they think will better protect and guarantee their rights.

Thus, as it can be understood, the origin and the justification of the state's legitimate power over its citizens, people uprisings in cases of government malfunctioning, as well as the property's role in the social development are all influenced by the earlier social contract theories of Hobbes, Lock and Rousseau, but also of later philosophers which contributed in developing this theory. This proves why the social contract is still relevant today, and this is why the study of its historical evolution is very important and helpful in the understanding of today's political, economic and social functioning of the society.

\section{References}

Barker, ed. (1985) Social Contract. Oxford: Oxford University Press.

Danny, Frederick (2013) Social Contract Theory Should Be Abandoned. Vol. 4.

Evers, Williamson M. (1977) "Social Contract: a Critique ." Journal of Libertarian Studies, Vol. 1, No. 3, 185-194. Pergamon Press, Great Britain.

Hobbes, Thomas (1651) Leviathan. Yale University Press, 2010.

Hoffmann, Bert (2011) "The International Dimensions of Authoritarian Legitimation: The Impact of Regime Evolution." GIGA Research Programme: Legitimacy and Efficiency of Political Systems.

Locke, John (1823) Two Treatises of Government. London.

Paz-Fuch, Amir (2011) The social contract revisited: The modern welfare state. Oxford: The Fundation for Law, Justice and Society.

Riley, Patrick (1976) Patrick Riley, "Locke on 'Voluntary Agreement' and Political Power", Vol. 29, No. 1. United States: Western Political Quarterly.

Rogers, G.A.J. And Tom Sorell (2003) Hobbes And History. Routledge, London And New York.

Rousseau, Jean Jacques (1762) Social Contract. Simon and Schuster, 2010.

Sokolowski, Asaf Z. (2011) Metaphysical Problems, Political Solutions Self, State, And Nation In Hobbes And Locke. Lexington Books, United Kingdom.

Weber, Eric Thomas. Social Contract Theory, Old And New. The Review Journal Of Political Philosophy. Volume 7.

British Broadcasting Corporation http://www.bbc.co.uk/news/world-europe-25342698 (December 10, 2013).

Top Channel http://www.top-channel.tv/english/artikull.php?id=10279 (December 12, 2013).

Gazeta Online Panorama http://www.panorama.com.al/2013/11/16/rama-thote-jo-shqiperia-e-ka-te-pamundur-te-perfshihet-ne-njeoperacion-te-tille-feste-para-kryeministrise/ (December 12, 2013).

Portali albeu.com http://www.albeu.com/shqiperi/ambientalistet-proteste-para-kryeministrise-ndal-armeve-kimike-nga-s/130957/ (December 12, 2013).

The New York Times http://topics.nytimes.com/top/news/international/countriesandterritories/ukraine/ (December 10, 2013).

Boucher, David and Paul Kelly (2005) The Social Contract From Hobbes To Rawls. Routledge, London.

Laslett, P. Second Treatise of Government in Two Treatiser of Government. cd. (New York: New American Library).

Machan, Tibor R. (1983) Social Contract As A Basis Of Norms: A Critique. The Journal Of Libertarian Studies. Vol. VII, Nr. I.

Makarkin, A. And Oppenheimer, P. M. (2011) The Russian social contract and regime legitimacy. International Affairs, 87: 1459-1474.

Nyamaka, Daudi Mwita. Social Contract Theory Of John Locke (1932-1704) In The Contemporary World. From The Selected works Of Daudi Mwita Nyamaka. (2011) Available at "http://works.bepress.com/dmnyamaka/5" Http://Works.Bepress.Com/Dmnyamaka/5

Stanila, Ana Maria. Nature and Society with Th. Hobbes and J.J. Rousseau. The Scientific Journal of Humanistic Studies, Year 4, no. 7.

Gazeta Online Panorama http://www.panorama.com.al/2013/11/07/ambientalistet-proteste-para-kryeministrise-ndal-armeve-kimike-ngasiria (November 12, 2013).

Portali albeu.com http://www.albeu.com/shqiperi/protesta-kunder-asgjesimit-te-armeve-te-sirise/131033/ (December 12, 2013).

Gazeta Online Panorama http://www.panorama.com.al/2013/11/12/prishtine-proteste-kunder-asgjesimit-te-armeve-kimike-ne-shqiperi/ (December 12, 2013).

Gazeta Online Panorama http://www.panorama.com.al/2013/11/13/revolte-e-fansave-ne-facebook-rama-pa-frike-nese-marrim-vendiminper-armet/ (December 12, 2013).

Portali albeu.com http://www.albeu.com/shqiperi/protesta-ne-durres-e-elbasan-/131760/ (December 12, 2013).

Gazeta Online Panorama http://www.panorama.com.al/2013/11/15/vendimi-i-rames-lajmi-ne-mediat-boterore/ (December 12, 2013).

Encyclopaedia Britannica. http://www.britannica.com/EBchecked/topic/157129/democracy/233861/The-legitimacy-of-government (December 10, 2013).

The Nuclear Threatlnitiative(NTI) http://www.nti.org/gsn/article/syrian-chemical-weapons-seen-likely-ship-albania-destruction/ (December 12, 2013). 